Egypt. Poult. Sci. Vol. (41) (I): (175-187)(2021)

Egyptian Poultry Science Journal

http://www.epsj.journals.ekb.eg/

ISSN: 1110-5623 (Print) - 2090-0570 (Online)

\title{
EFFECT OF DIFFERENT SEASONS ON GROWTH PERFORMANCE, IMMUNE RESPONSES AND ANTIOXIDANT STATUS OF BROILER CHICKENS
}

Youssef, S.F. ${ }^{1}$; Abdelfattah, M. H.; and Marwa, M. Bahnas ${ }^{2}$

${ }^{1}$ Anim. Prod. Res. Inst., Agric. Res. Center, Dokki, Giza, Egypt.

${ }^{2}$ Fac. of Agric., Fayoum Uni.

Corresponding author: Youssef, S.F Email: sabbah.farouk@arc.sci.eg

Received: 30/01/2021 Accepted: 05/03/2021

ABSTRACT: The current experiment was carried out in farm nearby Fayoum research station to study effect of different seasons on growth performance of broiler chicks and detect early indicators for supplementing broilers flocks with antioxidant and immune enhancer. Four flocks from Arbor Acres broiler chicks were reared during summer, autumn, winter, and spring seasons in open side system. Productive performance parameters, complete blood count, antibody titers against Newcastle (NDV), antibody titers against avian influenza $\left(\mathrm{H}_{5} \mathrm{~N}_{1}\right)$ and some antioxidant parameters were measured. The following results were obtained:

Body weight and body weight gain recorded significantly the highest values during spring seasons but the highest $(\mathrm{P} \leq 0.05)$ feed intake value was recorded during winter seasons and the best feed conversion value was recorded during autumn $(\mathrm{P} \leq 0.05)$. Total leukocytes count, heterophilus $(\mathrm{H})$, lymphocyte $(\mathrm{L})$ and $\mathrm{H} / \mathrm{L}$ ratio were not affected by different seasons. Antibody titers against NDV and $\mathrm{H}_{5} \mathrm{~N}_{1}$ record the highest significant values during summer season while the worst significant antioxidant status recorded during summer season. In contrast during winter values of antibody titers against NDV and $\mathrm{H}_{5} \mathrm{~N}_{1}$ were significantly the worst but antioxidant parameters recorded significantly the best values.

The results of the current study suggested that during winter flocks may need double doses from NDV and $\mathrm{H}_{5} \mathrm{~N}_{1}$ vaccines. However, during summer and autumn seasons, increasing antioxidant supplementation in diets or even drinking water is recommended.

Key words: Broilers, season, Performance, Antioxidants, immunity. 


\section{INTRODUCTION}

Geographically, ninety percent or more from Egypt lies inside the Sahara desert, thus Egypt climate classified as subtropical and tropical climate. Significant fluctuations in temperatures occurred not only during different season but it is fluctuated daily. In broiler field, prediction of adverse and harms effects that produced from climate fluctuation can be used as an early index for detecting disorders and how broiler breeder treat their flocks in different seasons. Kadim et al. (2008) reported that temperatures of different season effected significantly on broiler performance in flocks reared in houses with open-sided. Ipek and Sahan (2006) reported that there were significant differences in body weight, growth rate, feed consumption and feed conversion between broiler chicks that reared in cool temperature $\left(21^{\circ} \mathrm{C}\right)$ than control that reared in $33.3^{\circ} \mathrm{C}$ after three week of age. Moreover Olfati et al. (2018) reported that exposing broiler chicks to heat stress $\left(33 \pm 3^{\circ} \mathrm{C}\right)$ led to a decrease in feed intake by $14.90 \%$, body weight gain by $25.71 \%$ and an increase in feed conversion ratio by $13.06 \%$ compared with broiler reared under good condition $\left(24 \pm 2{ }^{\circ} \mathrm{C}\right)$. They added that when broiler chicks exposed to cold stress $\left(12 \pm 1^{\circ} \mathrm{C}\right)$, this led to decrease feed intake by $22.05 \%$ and body weight gain decreased by $38.32 \%$ but feed conversion ratio increased by $22.47 \%$ compared with that reared in good condition $\left(24 \pm 2^{\circ} \mathrm{C}\right)$.

The antioxidant resistance systems in poultry include endogenous (internally) antioxidant enzymes such glutathione peroxidase and glutathione reductase. Exogenous (externally) antioxidant includes supplied vitamins like E, B and C (Surai et al, 2019). The levels of vitamins in broiler diets (starter, grower or finisher) that formatted according to NRC (1994) had ability to satisfy broiler requirements from externally antioxidant reared in natural conditions nevertheless, stressed broiler chicks may be need more amount from antioxidant sources.

Complete blood count may be differed depending on broiler strain and season effect where, Mohamed et al. (2012) reported that response of 3 broiler strains (Cobb, Hubbard and Ross) for flocks reared in winter compared with summer season differ depending on broiler strain. Ipek and Sahan (2006) reported that cool temperature exhibited significant changes at $5 \mathrm{wk}$ of age in red blood cell counts, hemoglobin and hematocrit. Immune response in grower chickens affected by environmental temperatures where cellular immunity that represented in white blood cells and heterophil/lymphocyte ratio were affected by heat stress (Mashaly et al., 2004). On the other hand heat stress reduced antibody production in grower chickens (Zulkifi et al., 2000). Olfati et al. (2018) reported that cold and heat stress decreased antibody titer, lymphocyte count and increased heterophil and heterophil/lymphocyte ratio. In general cold stress caused retardation in immune function ( Zhao et al. 2014)

The present experiment was carried out to study effect of different seasons on growth performance and set early indicators for broiler producers to estimate how they can treat its flocks and supplementing immunity enhancers and antioxidant.

MATERIALS AND METHODS Flocks rearing, housing and management:

Four flocks each of which contains 450 one-day- old Arbor Acres broiler chicks 
Broilers, season, Performance, Antioxidants, immunity.

were reared during the four quarters of the year. The first flock reared in summer season during the period extended from 12 June to 16 July. The second flock reared in autumn season during the period extended from 5 November up to 9 December. The third flock reared in winter season during the period extended from 4 January 7 February. The last flock reared in spring season during the period extended from 14 March 17 April. All flocks that reared in this trail were reared in the same house with open side system. The ambient temperatures were adjusted to be $33{ }^{\circ} \mathrm{C}, 30^{\circ} \mathrm{C}$ and $26^{\circ} \mathrm{C}$ for the first three weeks respectively especially during winter and spring seasons, while during summer ambient temperature increased than this limit during the first three weeks especially through the daytime. Ambient temperature of the flock that reared during summer season were $38^{\circ} \mathrm{C}, 36^{\circ} \mathrm{C}, 38^{\circ} \mathrm{C}, 39^{\circ} \mathrm{C}$ and $38^{\circ} \mathrm{C}$ respectively for the five weeks of the current experiment. During winter season the average ambient temperature were $20^{\circ} \mathrm{C}$ and $18^{\circ} \mathrm{C}$ for the $4^{\text {th }}$ and $5^{\text {th }}$ weeks of experimental period but during spring the average ambient temperature were $24^{\circ} \mathrm{C}$ and $24^{\circ} \mathrm{C}$ for the $4^{\text {th }}$ and $5^{\text {th }}$ weeks of experimental period. During autumn the average ambient temperature were 28 , $26^{\circ} \mathrm{C}$ and $25^{\circ} \mathrm{C}$ for $3^{\text {rd }}, 4^{\text {th }}$ and $5^{\text {th }}$ weeks of experimental period. The relative humidity were recorded daily and the average calculated weekly for the four flocks where the average relative humidity was summarized in table (1).

At one - day - old broiler chicks of each flocks were weighed and distributed into 45 cages where each cages contains 10 chicks treated as one unit to estimate feed intake and body weight hence, feed conversion and body weight gain were calculated for each cage. Chicks were fed starter diet from 1-12 day of age, grower diet from 13-24 day of age and finisher diet from 25-35 day of age. Composition and calculated analyses of experimental diet were illustrated in Table 2 and all broiler chicks were fed ad libitum. Parameters of growth performance were measured and calculated weekly. The day light was supplemented with artificial clear light to obtain continuous light for entire experimental period where clear lamps (1 lamb/16m ${ }^{2}$ ) were used.

All flocks vaccinated against Newcastle disease (NDV) where it received Hitchner B1 strain at 6 days of age and LaSota strain at 16 and 26 days of age all in drinking water after thirsty for two hours. Oil Vaccine against NDV $\left(0.5 \mathrm{~cm}^{3} /\right.$ bird $)$ was injected in thigh at 13 day of age. Moreover Oil Vaccine against avian influenza $\mathrm{H}_{5} \mathrm{~N}_{1} \quad\left(0.5 \mathrm{~cm}^{3} /\right.$ bird $)$ was injected in thigh at 9 day of age.

\section{Samples and biochemical assays:}

When each flocks reached 35 day of age 10 blood samples were withdrawn randomly in heparinized test tubes to estimate total antioxidant capacity (TOAC) and malondialdehyde MDA. Ten blood samples from each flocks either were withdrawn randomly in non-heparinized test tubes to determine antibody titer against Newcastle diseases (AbNDV) and avian influenza $\mathrm{H}_{5} \mathrm{~N}_{1}$ $\left(\mathrm{AbH}_{5} \mathrm{~N}_{1}\right)$. Moreover 10 heparinized blood samples were withdrawn to evaluate complete blood count (CBC) and another 10 heparinized blood samples were withdrawn to estimate glutathione peroxidase (GPx) and glutathione reductase (GS-r).

The test of AbNDV conducted by using preventing from hemagglutination method and the test of $\mathrm{AbH}_{5} \mathrm{~N}_{1}$ were conducted by using commercial Elisa Kits in Reference Lab for Veterinary Quality Control on Poultry Production, Egypt. Ten broiler chicks were slaughtered to estimate Carcass characteristics. 
Youssef, S.F. ${ }^{1}$ et al.

Statistical analysis: Data of all
experimental flocks were statistical
analyzed using one way ANOVA
procedure (spss, 2007). Variables showed
significant differences at F-test (P $\leq 0.05$
or less) were compared to each other's
using Duncan's Multiple Range Test
(Duncan, 1955).

\section{RESULTS AND DISCUSSION} Growth performance:

Body weight (BW) and body weight gain (BWG) were affected significantly by season's differences. Summer season caused significant retardation in BW and BWG compared with other seasons during grower, finisher and entire growth period. In contrast, growing broiler during spring significantly achieved the highest BW during grower and entire periods. Winter season followed spring season in improving BW and BWG. For all stages of growing periods winter season achieved significant improvement in BW and BWG compared with summer season and these results in a full agreement with Osti et. al. (2017) who reported that body weight was significantly greater during winter compared with summer season and similar results obtained by Ipek and Sahan (2006) and Osti et. al. (2017). This is may be due to heat stress during summer season caused harm effect in BW and BWG where Yousaf et. al. (2019) reported that heat stress caused harmful effect on BW and Liu et al (2020) reported that heat stress decreased BWG. Feed intake was affected significantly by different seasons where feed intake of broiler chicks that reared in winter seasons recorded significantly the highest values followed by spring season especially for Entire period. In contrast the lowest significantly values of feed intake recorded during autumn season followed by summer season. Regarding retardation of feed intake during summer season this may be due to heat stress during summer season significantly decreased feed intake (Liu et al, 2020). Decreasing FI during summer season may be due either to feed was lifted far from broiler chickens at midday to 4PM during the last two weeks of age.

The lowest values $(p \leq 0.05)$ for FI were recorded during finisher and entire periods at autumn season this may be due to the average values of relative humidity during this season (Table, 1) was the highest values. Relative humidity and high ambient temperature were thermal factors that reduced feed intake (Mascarenhas et al, 2020). On the same manner Ying et al (2019) reported that relative humidity decreased average daily feed intake. Feed conversion (FC) affected significantly by different seasons as shown in Table 3. The worst FC values recorded during winter seasons and this result was in a full agreement with Osti et. al. (2017) who reported that broiler chicks that reared during winter FC had significantly $(p \leq 0.05)$ higher $F C$ than that reared in other seasons. Increasing FI during winter may be due to energy that used for maintenance in broiler chickens may increase during this season and this in a full agreement with Nogueira et. al. (2013) who reported that energy requirements that used for maintenance during winter was increased.

\section{Carcass characteristics:}

Data in Table (4) indicated that each of Giblets, Abdominal fat $\%$, heart $\%$ and spleen $\%$ didn't affected significantly by different seasons in contrast dressing $\%$, liver\% and gizzard\% affected significantly by different seasons. Dressing percentage differ significantly $(p \leq 0.002)$ depending on seasons 
Broilers, season, Performance, Antioxidants, immunity.

different. During summer seasons broiler chicks yielded significantly $(\mathrm{p} \leq 0.05)$ lower dressing weight percentage compared with winter season. This results was disagreement with Sarma et al (2020) who found higher dressing percentage for broiler reared during summer but lowest percentage for broiler reared during winter season. Our results may be more logical because final body weight of broiler reared in winter recorded higher values compared with than final body weight of broiler reared in summer. The results of Humam et al 2019 demonstrated that as final body weight increase as dressing weight percentage increase. Insignificant effect of seasons was observed on giblets weight percent and this result was in agreement with Sarma et al (2020). Moreover Yousaf et. al. (2019) reported that summer season caused significant decrease in dressing weight percentage.

\section{Complete blood count:}

Results in Table 5 indicated that each of red blood cells (RBCs) hemoglobin $(\mathrm{Hb})$ and hematocrit $(\mathrm{Ht} \%)$ were affected significantly by different seasons. Broiler chickens of flocks that reared during summer seasons recorded significantly the lowest $\mathrm{RBCs}, \mathrm{Hb}$ and $\mathrm{Ht} \%$ values. The result of RBCs during summer season was in a full agreement with Donkoh (1989) who reported that decreased in RBCs, $\mathrm{Hb}$ and $\mathrm{Ht} \%$ were observed in broiler reared in temperature ranged from $30-35{ }^{\circ} \mathrm{C}$ he presented data indicated that decreasing ambient temperature increased $\mathrm{RBCs}, \mathrm{Hb}$ and $\mathrm{Ht} \%$. Moreover, Yahav and Hurwtiz 1996 reported that exposure to high temperature, decreased hematocrit and similar results was obtained by Mohamed et al. (2012) who reported that RBCs, Hb and $\mathrm{Ht} \%$ were decreased during summer season compared with winter season.

\section{Immune responses:}

The results of cellular immunity (Table, 5) demonstrated that different seasons didn't affect white cell profile where heterophil $(\mathrm{H})$, lymphocyte $(\mathrm{L})$ and $\mathrm{H} / \mathrm{L}$ ratio didn't differ significantly among the four seasons. Insignificant effect of seasons on white cell profile may be due to all flocks during different seasons reared in broiler cages that may be reduced exposing broiler chickens to pathogenic bacteria. Moreover the four flocks were treated equally in regarding to supplementing antibiotics when chickens exposed to pathogenic bacteria. The results of humoral immunity indicated that during summer season $\mathrm{AbNDV}$ and $\mathrm{AbH}_{5} \mathrm{~N}_{1}$ recorded significantly the highest values but during winter it recorded the lowest values (Table, 5).

Regarding white blood cell profile the results were in a full agreement with Osti et al., (2017) and similar results obtained by Yalcin, et al. (2004). Regarding results of AbNDV cold stress affected AbNDV depending on chicken strain (Spinu and Degen, 1993) and during winter vaccination improved AbNDV immediately in the flocks (Bari et al. 2018). Hence titer of AbNDV may be lowered quickly during winter where experimental flocks were vaccinated at 26 day of age then samples were withdrawn at 35 day of age so AbNDV depressed. Moreover Xylouri-Frangiadaki and Samouhos (2000) reported that level of AbNDV offer adequate protection for NDV disease during summer season. Li et al.(2020) reported that number of LaSota vaccine doses affected AbNDV and growth performance in vaccinated broiler chickens. So in winter it may be suitable to vaccinate the first dose of 


\section{Youssef, S.F. ${ }^{1}$ et al.}

LaSota more early at 11, 21 and insert more one dose at 31 day of age. Increasing efficiency of NDV vaccination may be applied by increasing single dose (1000 dose per 1000 bird) to be double dose (2000 dose per 1000 bird). Where Igwe et al. (2019) suggested that vaccinated LaSota with a double dose procedure improved vaccine performance for controlling velogenic of Newcastle disease. Moreover

\section{Antioxidant status:}

Regarding antioxidant plasma component (TAOC and MDA) of broiler chickens, the data in Table (5) indicated that both of TAOC and MDA were affected significantly by different seasons. The TAOC values recorded significantly the highest values during winter seasons followed by spring, autumn and summer respectively. In contrast MDA showed an opposite arrangement, where MDA values in plasma of broiler chickens recorded significantly the highest values during summer season followed by autumn, winter and spring respectively. The data of antioxidant enzymes Table (5) indicated that seasons affected significantly $(p \leq 0.001)$ on GPx, nevertheless GS-r was not affected. Heat exposure as a chronic heat stress that occurred during summer season depressed sharply $(\mathrm{p} \leq 0.05)$ GPx and this depression were alleviated as environmental temperature decreased during autumn and spring. In contrast during winter season and when broiler chicks exposed to chronic cold stress, the results exhibiting significant improvement in GPx and insignificant improvement in GS-r.

The reduction in antioxidant plasma component and antioxidant enzymes during summer and autumn seasons may be due to free radical increased as environmental temperature increased. Moreover the data of growth performance recorded significant decrease in feed intake as environmental temperature increased hence, consumption of external antioxidant (such vitamins mainly $\mathrm{E}$ and $\mathrm{C}$ and minerals mainly selenium) that supplemented in diets formatted according to NRC (1994) were decreased. Decreasing antioxidant activities, agree with (Ando et al., 1997) who reported that heat stress increased free radical through disturbance of electron transport in cell membrane may be by cussing molecular changes in primly lipids, proteins, DNA, and other molecules (Bruskov et al., 2002).

Free radical (FRs) divided into two main categories that include reactive nitrogen species and reactive oxygen species where equilibrium between FRs and antioxidants is important for keeping physiological function (Lobo et al., 2010). Antioxidant system involves internally substances mainly include GPx and externally substances like vitamins E and C (Surai et al., 2019). Reactive oxygen byproducts resulted from aerobic reactions then accumulated in the cell and produced toxic status for cell (Margis, et al., 2008). They added that reactive oxygen produced superoxide, hydroxyl and hydrogen peroxide radicals.

In general alleviating side effect of free radical and improving antioxidant statues during winter and spring seasons may be due to chickens during the first three weeks reared in optimal temperature and the ambient temperature decreased during the last two weeks to be near optimal temperature or slightly less. On the other hand during summer season ambient temperatures during different weeks of rearing periods (1-5wks) were higher than optimal temperature as indicated in Table 


\section{Youssef, S.F. ${ }^{1}$ et al.}

(1). The ambient temperature during summer season may be caused heat stress that increased lipid peroxidation as pointed from MDA values (table, 5) and free radical may be increased generation of MDA (Altan et al., 2003) and superoxide production is significantly increased by heat stress (Mujahid et al., 2005)

\section{CONCLUSION}

The results from this study indicated that broiler during summer season may need excess amount of antioxidant higher than recommendation of NRC (1994). The results indicated either that flocks reared during winter may needexcess amount of immune enhancer drugs and may need either increasing efficiency of vaccination techniques through application of double dose procedure or decreasing vaccination interval period specially for LaSota vaccine

Table (1): Ambient temperature and relative humidity for four year seasons.

\begin{tabular}{|l|c|c|c|c|c|c|c|c|}
\hline \multirow{2}{*}{ Season } & \multicolumn{2}{|c|}{ Summer } & \multicolumn{2}{c|}{ Autumn } & \multicolumn{2}{c|}{ Winter } & \multicolumn{2}{c|}{ Spring } \\
\cline { 2 - 8 } Week & T & RH & T & RH & T & RH & T & RH \\
\hline First & 38 & 35 & 33 & 40 & 33 & 30 & 33 & 35 \\
Second & 36 & 40 & 30 & 50 & 30 & 35 & 30 & 40 \\
Third & 38 & 45 & 28 & 50 & 26 & 45 & 26 & 45 \\
Fourth & 39 & 35 & 26 & 45 & 20 & 45 & 24 & 35 \\
Fifth & 38 & 35 & 25 & 45 & 18 & 45 & 24 & 35 \\
Average & 37.8 & 38 & 28.4 & 46 & 25.2 & 40 & 27.4 & 38 \\
\hline
\end{tabular}


Youssef, S.F. ${ }^{1}$ et al.

Table(2): Composition and calculated analysis of Starter, grower and finisher diets.

\begin{tabular}{|c|c|c|c|}
\hline Composition (per 100 Kg) & $\begin{array}{c}\text { Starter } \\
\text { (1-10 day) }\end{array}$ & $\begin{array}{c}\text { Grower } \\
\text { (11-24day) }\end{array}$ & $\begin{array}{c}\text { Finisher } \\
(25-40 \text { day })\end{array}$ \\
\hline Yellow Corn & 52.28 & 59.05 & 63.19 \\
\hline Soybean meal (44\%CP) & 34.00 & 26.70 & 22.5 \\
\hline Corn gluten $(60 \% \mathrm{CP})$ & 6.00 & 7.00 & 6.30 \\
\hline Oil & 3.00 & 3.00 & 4.00 \\
\hline Di-Calcium phosphate & 1.84 & 1.67 & 1.59 \\
\hline Lime stone & 1.43 & 1.20 & 1.10 \\
\hline L- Lysine Hcl & 0.32 & 0.31 & 0.28 \\
\hline Dl -Methionine & 0.26 & 0.20 & 0.17 \\
\hline Sodium Chloride & 0.24 & 0.24 & 0.24 \\
\hline Sodium bicarbonate & 0.23 & 0.23 & 0.23 \\
\hline Vitamins Premix $*$ & 0.10 & 0.10 & 0.10 \\
\hline Minerals Premix** & 0.30 & 0.30 & 0.30 \\
\hline Total & 100.00 & 100.00 & 100.00 \\
\hline \multicolumn{4}{|l|}{ Calculated analysis \% } \\
\hline Crude Protein & 23.17 & 21.25 & 19.04 \\
\hline Metabolizable Energy (Kcal/Kg) & 3100 & 3110 & 3207 \\
\hline Ether extract & 5.63 & 5.08 & 6.88 \\
\hline Crude fiber & 3.80 & 3.45 & 3.22 \\
\hline Calcium & 1.04 & 0.90 & 0.84 \\
\hline Av. Phosphorus & 0.50 & 0.45 & 0.43 \\
\hline Lysine & 1.44 & 1.24 & 1.09 \\
\hline Methionine & 0.68 & 0.60 & 0.54 \\
\hline Methionine+Cyctine & 1.06 & 0.95 & 0.86 \\
\hline
\end{tabular}

* Supplied per kg of diet: Vit. A, 11000 IU; Vit. D3, 5000 IU; Vit. E, 50 mg; Vit K3, 3mg; Vit. B1, 2mg; Vit. B2 6mg; B6 3 mg; B12, 14 mcg; Nicotinic acid 60mg; Folic acid $1.75 \mathrm{mg}$, Pantothenic acid 13mg; and Biotine 120 mcg.

**Supplied per $\mathrm{kg}$ of diet: Choline $600 \mathrm{mg}$; Copper 16mg; Iron 40mg; Manganese $120 \mathrm{mg}$; Zinc 100mg; Se $0.20 \mathrm{mg}$ and Idoine $1.25 \mathrm{mg}$. 
Broilers, season, Performance, Antioxidants, immunity.

Table (3): Effet of diffèrent sassons on growth performance.

\begin{tabular}{|c|c|c|c|c|}
\hline \multicolumn{5}{|c|}{ Body weight (g) } \\
\hline Seasons & 1 day & Starter & Grower & Finisher \\
\hline Summer & $41.56 \pm 0.13$ & $183.24^{\mathrm{b}} \pm 2.20$ & $659.27^{\mathrm{d}} \pm 18.93$ & $1529.01^{\mathrm{d}} \pm 29.92$ \\
\hline Autumn & $42.71 \pm 0.18$ & $178.55^{\mathrm{b}} \pm 3.05$ & $729.33^{c} \pm 15.67$ & $1632.45^{\mathrm{c}} \pm 34.50$ \\
\hline Winter & $41.00 \pm 0.00$ & $203.26^{\mathrm{a}} \pm 0.91$ & $795.68^{\mathrm{b}} \pm 20.07$ & $1941.00^{\mathrm{b}} \pm 27.20$ \\
\hline Spring & $42.11 \pm 0.13$ & $214.72^{\mathrm{a} \pm 1.74}$ & $875.73^{\mathrm{a} \pm 10.35}$ & $2027.69^{\mathrm{a}} \pm 27.76$ \\
\hline $\mathrm{P}$ values & NS & 0.001 & 0.001 & 0.001 \\
\hline \multicolumn{5}{|c|}{ Body weight gain (g) } \\
\hline & Starter & Grower & Finisher & Entire period \\
\hline Summer & $141.64^{\mathrm{b}} \pm 2.16$ & $476.03^{\mathrm{d}} \pm 19.45$ & $869.74^{\mathrm{b}} \pm 14.70$ & $1487.41^{\mathrm{d}} \pm 30.02$ \\
\hline Autumn & $137.47^{\mathrm{b}} \pm 3.11$ & $550.78^{\mathrm{c}} \pm 13.84$ & $903.12^{\mathrm{b}} \pm 24.60$ & $1591.37^{\mathrm{c}} \pm 34.53$ \\
\hline Winter & $161.22^{\mathrm{a}} \pm 0.89$ & $592.42^{\mathrm{b}} \pm 19.44$ & $1145.32^{\mathrm{a}} \pm 8.56$ & $1898.96^{\mathrm{b}} \pm 27.19$ \\
\hline Spring & $172.06^{\mathrm{a}} \pm 1.74$ & $661.01^{\mathrm{a}} \pm 10.14$ & $1151.97^{\mathrm{a}} \pm 19.61$ & $1985.03^{\mathrm{a}} \pm 27.72$ \\
\hline $\mathrm{P}$ values & 0.001 & 0.001 & 0.001 & 0.001 \\
\hline \multicolumn{5}{|c|}{ Feed intake $(\mathrm{g})$} \\
\hline & Starter & Grower & Finisher & Entire period \\
\hline Summer & $193.15^{\mathrm{b}} \pm 2.85$ & $735.27^{\mathrm{b}} \pm 14.01$ & $1408.02^{c} \pm 26.82$ & $2336.44^{\mathrm{b}} \pm 30.03$ \\
\hline Autumn & $181.51^{\mathrm{c}} \pm 2.43$ & $756.33^{\mathrm{b}} \pm 15.33$ & $1332.53^{\mathrm{d}} \pm 38.37$ & $2270.38^{c} \pm 45.04$ \\
\hline Winter & $221.47^{\mathrm{a}} \pm 1.16$ & $975.32^{\mathrm{ab}} \pm 3.04$ & $1926.47^{\mathrm{a}} \pm 21.10$ & $3123.26^{\mathrm{a}} \pm 23.23$ \\
\hline Spring & $217.36^{\mathrm{a}} \pm 4.72$ & $1008.82^{\mathrm{a}} \pm 9.42$ & $1842.40^{\mathrm{b}} \pm 11.19$ & $3068.58^{\mathrm{b}} \pm 12.33$ \\
\hline $\mathrm{P}$ values & 0.001 & 0.001 & 0.001 & 0.001 \\
\hline \multicolumn{5}{|c|}{ Feed conversion ( $\mathrm{g}$ feed/g gain) } \\
\hline & Starter & Grower & Finisher & Entire period \\
\hline Summer & $1.37^{\mathrm{a}} \pm 0.02$ & $1.57^{\mathrm{b}} \pm 0.05$ & $1.62^{\mathrm{a}} \pm 0.04$ & $1.58^{\mathrm{b}} \pm 0.04$ \\
\hline Autumn & $1.32^{\mathrm{ab}} \pm 0.02$ & $1.38^{\mathrm{c}} \pm 0.02$ & $1.48^{\mathrm{b}} \pm 0.03$ & $1.43^{\mathrm{c}} \pm 0.02$ \\
\hline Winter & $1.37^{\mathrm{a}} \pm 0.01$ & $1.68^{\mathrm{a}} \pm 0.05$ & $1.68^{\mathrm{a}} \pm 0.01$ & $1.65^{\mathrm{a}} \pm 0.01$ \\
\hline Spring & $1.26^{\mathrm{b}} \pm 0.03$ & $1.53^{\mathrm{b}} \pm 0.03$ & $1.60^{\mathrm{ab}} \pm 0.03$ & $1.55^{\mathrm{b}} \pm 0.02$ \\
\hline $\mathrm{P}$ values & NS & 0.010 & 0.001 & 0.002 \\
\hline
\end{tabular}

$a, b, \ldots=$ Means in the same column with different superscripts, differ significantly $(\mathrm{p} \leq 0.05) ; \mathrm{NS}$ $=$ Not Significant $(\mathrm{p} \leq 0.05$

Table (4): Effet of diffèrent sassons on carcass characteristics.

\begin{tabular}{|l|c|c|c|c|c|c|c|}
\hline Season & Dressing\% & Giblets\% & $\begin{array}{l}\text { Abdominal } \\
\text { fat\% }\end{array}$ & Liver \% & Heart \% & $\begin{array}{c}\text { Gizzard } \\
\%\end{array}$ & $\begin{array}{c}\text { Spleen } \\
\%\end{array}$ \\
\hline Summer & $67.02^{\mathrm{b}} \pm 0.84$ & $4.68 \pm 0.08$ & $1.68 \pm 0.04$ & $2.47^{\mathrm{a}} \pm 0.06$ & $0.53 \pm 0.02$ & $1.59^{\mathrm{b}} \pm 0.04$ & $0.14 \pm 0.00$ \\
Autumn & $69.41^{\mathrm{a}} \pm 1.07$ & $4.75 \pm 0.09$ & $1.74 \pm 0.05$ & $2.33^{\mathrm{a}} \pm 0.06$ & $0.56 \pm 0.02$ & $1.71^{\mathrm{a}} \pm 0.03$ & $0.15 \pm 0.01$ \\
Winter & $71.41^{\mathrm{a}} \pm 0.26$ & $4.88 \pm 0.04$ & $1.71 \pm 0.04$ & $2.42^{\mathrm{a}} \pm 0.03$ & $0.58 \pm 0.01$ & $1.76^{\mathrm{a}} \pm 0.03$ & $0.15 \pm 0.01$ \\
Spring & $70.14^{\mathrm{a}} \pm 0.63$ & $4.45 \pm 0.07$ & $1.56 \pm 0.10$ & $2.18^{\mathrm{b}} \pm 0.04$ & $0.53 \pm 0.01$ & $1.60^{\mathrm{b}} \pm 0.03$ & $0.14 \pm 0.00$ \\
P values & 0.002 & NS & NS & 0.001 & NS & 0.002 & NS \\
\hline
\end{tabular}

$a, b, \ldots=$ Means in the same column with different superscripts, differ significantly $(\mathrm{p} \leq 0.05)$.

NS $=$ Not Significant $(\mathrm{p} \leq 0.05)$ 
Table (5): Effect of different season on complete blood count, immune responses and antioxidant status.

\begin{tabular}{|c|c|c|c|c|c|c|c|c|c|c|c|c|}
\hline \multirow{3}{*}{\begin{tabular}{|l} 
Parameters \\
Season
\end{tabular}} & \multirow{2}{*}{\multicolumn{3}{|c|}{ Complete blood count }} & \multicolumn{5}{|c|}{ Immune responses } & \multicolumn{4}{|c|}{ Antioxidant status } \\
\hline & & & & \multicolumn{3}{|c|}{ Cellular immunity } & \multicolumn{2}{|c|}{ Antibody titer } & \multicolumn{2}{|c|}{ Component } & \multicolumn{2}{|c|}{ Enzymes } \\
\hline & $\begin{array}{l}\text { RBCs } \\
\times 10^{6}\end{array}$ & Hb & Ht\% & H\% & $\mathbf{L} \%$ & $\begin{array}{l}\mathrm{H} / \mathrm{L} \\
\text { ratio }\end{array}$ & AbNDV & $\mathrm{AbH}_{5} \mathbf{N}$ & $\begin{array}{l}\text { TOAC } \\
\mathrm{mmol} / \mathrm{l}\end{array}$ & $\begin{array}{l}\text { MDA } \\
\text { nmol/ml }\end{array}$ & $\begin{array}{l}\text { GPx } \\
(\mathbf{m U} / \mathrm{ml})\end{array}$ & $\begin{array}{l}\text { GS-r } \\
\text { )U/L( }\end{array}$ \\
\hline \multirow{2}{*}{ Summer } & $3.09^{\mathrm{c}}$ & $11.74^{\mathrm{c}}$ & $31.81^{\mathrm{c}}$ & 28.55 & 65.37 & 0.44 & $8.84^{\mathrm{a}}$ & $7.87^{\mathrm{a}}$ & $0.63^{\mathrm{d}}$ & $9.02^{\mathrm{a}}$ & $581.72^{d}$ & 7.93 \\
\hline & +005 & +025 & +0.56 & +036 & +035 & +0.01 & +003 & +0.04 & +009 & +091 & +2297 & +155 \\
\hline \multirow{2}{*}{ Autumn } & $3.34^{\mathrm{b}}$ & $13.74^{\mathrm{a}}$ & $35.96^{\mathrm{a}}$ & 28.77 & 64.55 & 0.45 & $7.86^{\mathrm{b}}$ & $6.85^{\mathrm{b}}$ & $0.78^{\mathrm{c}}$ & $5.64^{\mathrm{b}}$ & $655.36^{\mathrm{c}}$ & 13.44 \\
\hline & \pm 0.07 & \pm 0.08 & \pm 0.20 & \pm 0.47 & \pm 0.61 & \pm 0.01 & \pm 0.03 & \pm 0.05 & \pm 0.02 & \pm 0.23 & \pm 23.72 & \pm 0.34 \\
\hline \multirow{2}{*}{ Winter } & $3.44^{\mathrm{a}}$ & $12.96^{\mathrm{b}}$ & $34.01^{\mathrm{b}}$ & 28.85 & 65.54 & 0.44 & $6.40^{\mathrm{c}}$ & $6.02^{c}$ & $1.12^{\mathrm{a}}$ & $3.02^{\mathrm{c}}$ & $949.97^{\mathrm{a}}$ & 9.38 \\
\hline & \pm 0.12 & \pm 0.39 & \pm 0.91 & \pm 0.66 & \pm 0.69 & \pm 0.02 & \pm 0.17 & \pm 0.19 & \pm 0.11 & \pm 0.37 & \pm 18.49 & \pm 0.53 \\
\hline \multirow{2}{*}{ Spring } & $3.64^{\mathrm{a}}$ & $13.77^{\mathrm{a}}$ & $36.00^{\mathrm{a}}$ & 29.11 & 65.60 & 0.45 & $8.04^{b}$ & $7.09^{\mathrm{b}}$ & $1.02^{\mathrm{b}}$ & $2.91^{\mathrm{d}}$ & $707.95^{\mathrm{b}}$ & 9.15 \\
\hline & \pm 0.03 & \pm 0.10 & \pm 0.33 & \pm 0.75 & \pm 0.78 & \pm 0.02 & \pm 0.20 & \pm 0.24 & \pm 0.06 & \pm 0.45 & \pm 13.57 & \pm 0.58 \\
\hline $\mathrm{P}$ values & 0.039 & 0.015 & 0.031 & NS & NS & NS & 0.019 & 0.035 & 0.019 & 0.023 & 0.001 & NS \\
\hline
\end{tabular}

$\overrightarrow{\mathrm{a}}, \mathrm{b}, \ldots=$ Means in the same column with different superscripts, differ significantly $(\mathrm{p} \leq 0.05) \quad \mathrm{NS}=\mathrm{N}$
$+\mathrm{RBCs}=$ red blood cells $\mathrm{Hb}=$ hemoglobin $\mathrm{Ht} \%=$ hematocrit $\mathrm{H} \%=$ heterophil $\mathrm{L} \%=$ lymphocyte

$\mathrm{AbNDV}=$ antibody titer against Newcastle diseases $\quad \mathrm{AbH}_{5} \mathrm{~N}_{1}=$ antibody titer against avian influenza

TOAC $=$ total antioxidant capacity $\quad \mathrm{MDA}=$ malondialdehyde

$\mathrm{GPx}=$ glutathione peroxidase GS-r $=$ glutathione reductase 
Broilers, season, Performance, Antioxidants, immunity.

\section{REFERENCES}

Altan, Ö. Z. G. E.; Pabuçcuoğlu, A.; Altan, A.; Konyalioğlu, S.; and Bayraktar, H., 2003. Effect of heat stress on oxidative stress, lipid peroxidation and some stress parameters in broilers. Br. Poult. Sci. 44:545-550.

Ando, M.; Katagiri, K.; Yamamoto, S.; Wakamatsu, K.; Kawahara, I.; Asanuma, S.; Usuda, M.; and Sasaki, K. 1997. Agerelated effects of heat stress on protective enzymes for peroxides and microsomal monooxygenase in rat liver. Environ. Health Perspect. 105:726-733.

Bari, M. S.; Rana, E. A.; Abid, M. H.; Akter, N.; and Sayeed, M. A. 2018. Prevalence of poultry diseases in winter season in Chittagong and efficacy of challenge vaccine against Newcastle disease. Res. Agric., Livest. Fish. 5:201-208.

Bruskov, V. I.; Malakhova, L. V.; Masalimov, Z. K.; and Chernikov. A. V. 2002. Heat-induced formation of reactive oxygen species and 8oxoguanine, a biomarker of damage to DNA. Nucleic Acids Res. 30:13541363.

Donkoh, A. 1989. Ambient temperature: a factor affecting performance and physiological response of broiler chickens. Int. J. Biometeorol. 33:259265.

Duncan, D. B. 1955. Multiple range and multiple F tests. Biomet. 11: 1-42.

Humam, A. M.; Loh, T. C.; Foo, H. L.; Samsudin, A. A.; Mustapha, N. M.; Zulkifli, I.; and Izuddin, W. I. 2019. Effects of feeding different postbiotics produced by Lactobacillus plantarum on growth performance, carcass yield, intestinal morphology, gut microbiota composition, immune status, and growth gene expression in broilers under heat stress. Animals. 9:644-665.

Igwe, A. O.; Nnsewo, U. E.; Eze, D. C.; Abba, Y.; and Okoye, J. O. 2019. Increased doses of La Sota vaccine increased Newcastle disease antibody response significantly in broiler chickens (Gallus gallus domesticus). J. Appl. Anim. Res. 47:423-428.

Ipek, A.; and Sahan, U. 2006. Effects of cold stress on broiler performance and ascites susceptibility. Asian-australas. J. Anim. 19: 734-738.

Kadim, I. T.; Al-Qamshui, B. H. A.; Mahgoub, O.; Al-Marzooqi, W.; and Johnson, E. H. 2008. Effect of seasonal temperatures and ascorbic acid supplementation on performance of broiler chickens maintained in closed and open-sided houses. Int. J. Poult. Sci, 7, 655-660.

Li, R. F.; Liu, S. P.; Yuan, Z. H.; Yi, J. E.; Tian, Y.N.; Wu, J. and Wen, L. X. 2020. Effects of induced stress from the live LaSota Newcastle disease vaccination on the growth performance and immune function in broiler chickens. Poult. Sci. 99:18961905.

Liu, L.; Ren, M.; Ren, K.; Jin, Y.; and Yan, M. 2020. Heat stress impacts on broiler performance: a systematic review and meta-analysis. Poult. Sci. 99: 6205-6211.

Lobo, V.; Patil, A.; Phatak, A.; and Chandra, N. 2010. Free radicals, antioxidants and functional foods: Impact on human health. Pharmacogn. Rev. 4:118-126.

Margis, R.; Dunand, C.; Teixeira, F. K.; and Margis-Pinheiro, M. 2008. Glutathione peroxidase family-an evolutionary overview. FEBS J. 275:3959-3970.

Mascarenhas, N. M. H.; da Costa, A. 
Youssef, S.F. ${ }^{1}$ et al.

N. L.; Pereira, M. L. L.; de Caldas, A. C. A.; Batista, L. F.; and Andrade, E. L. G. 2020. Thermal conditioning in the broiler production: challenges and possibilities. J. Anim. Behav. Biometeorol. 6: 52-55.

Mashaly, M. M.; Hendricks, G. L.; Kalama, M. A.; Gehad, A. E; Abbas, A. O.; and Patterson, P. H., 2004. Effect of heat stress on production parameters and immune responses of commercial laying hens. Poult. Sci. 83:889-894.

Mohamed, E. A.; Ali, O. H.; Malik, E. E.; and Yousif, I. A. 2012. Effect of season and dietary protein level on some haematological parameters and blood biochemical compositions of three broiler strains. Int. J. Poult. Sci.11: 787-793.

Mujahid, A.; Yoshiki, Y.; Akiba, Y.; and Toyomizu, M. 2005. Superoxide radical production in chicken skeletal muscle induced by acute heat stress. Poult. Sci. 84:307-314.

Nogueira, W. C. L.; Velásquez, P. A. T.; Furlan, R. L. ;and Macari, M., 2013. Effect of dietary energy and stocking density on the performance and sensible heat loss of broilers reared under tropical winter conditions. Braz. J. Poult. Sci.15:5357.

NRC, National Research Council, 1994. Nutrient Requirements of Poultry. 9th revised edition. National Academy Press. Washington, D.C., USA.

Olfati, A.; Mojtahedin, A.; Sadeghi, T.; Akbari, M.; and Martínez-Pastor, F. 2018. Comparison of growth performance and immune responses of broiler chicks reared under heat stress, cold stress and thermoneutral conditions. Span. J. Agric. Res. 16: 15-
21.

Osti, R.; Bhattarai, D.; and Zhou, D. 2017. Climatic variation: effects on stress levels, feed intake, and bodyweight of broilers. Braz. J. Poult. Sci. 19: 489-496.

Sarma, M.; Islam, R.; Kalita, K. P.; Mahanta, J. D.; Sarmah, B. K.; and Bhattacharyya, B. N. 2020. Effect of seasons on carcass characteristics of broiler chicken under small scale production system. J. Entomol. Zool. Stud. 8: 776-781.

Spinu, M.; and Degen, A.A., 1993. Effect of cold stress on performance and immune responses of Bedouin and White Leghorn hens. Br. Poult. Sci. 34:177-185.

SPSS., 2007. SPSS Users Guide Statistics. Version 16. Copyright SPSS Inc., USA.

Surai, P. F.; Kochish, I. I.; Fisinin, V. I.; and Kidd, M. T. 2019. Antioxidant defence systems and oxidative stress in poultry biology: An update. Antioxid. 8:235-271.

Xylouri-Frangiadaki, E.; and Samouhos, M. 2000. Vaccine response to Newcastle disease virus in layers during summer months. J. Hellenic. Vet. Med. Soc. 51:140-144.

Yahav, S.; and Hurwtiz, S. 1996. Induction of thermotolerance in male broiler chickens by temperature conditioning at an early age. Poult. Sci., 75: 402-406.

Yalcin, S.; Özkan, S.; Oktay, G.; Cabuk, M.; Erbayraktar, Z.; and Bilgili, S.F., 2004. Age-related effects of catching, crating, and transportation at different seasons on core body temperature and physiological blood parameters in broilers. J. Appl. Poult. Res. 13:549-560.

Ying, Z.; Zhang, M. H.; Feng, J. H.; 
Broilers, season, Performance, Antioxidants, immunity.

and Diao, H. J. 2019. Effect of relative humidity at chronic temperature on growth performance, glucose consumption, and mitochondrial ATP production of broilers. J. Integr. Agric. 18:13211328.

Yousaf, A.; Jabbar, A.; Rajput, N.; Memon, A.; Shahnawaz, R.; Mukhtar, N.; Farooq, F.; Abbas, M.; and Khalil, R. 2019. Effect of environmental heat stress on performance and carcass yield of broiler chicks. World Vet J. 9: 26-30.
Zhao, F. Q.; Zhang, Z. W.; Qu, J. P.; Yao, H. D.; Li, M.; Li, S.; and Xu S. W. 2014. Cold stress induces antioxidants and Hsps in chicken immune organs. Cell Stress Chaperon. 19: $635-648$

Zulkifi, I.; Norma, M. T.; Israf, D. A.; and Omar, A. R. 2000. The effect of early age feed restriction on subsequent response to high environmental temperatures in female broiler chickens. Poult. Sci. 79:14011407.

\section{الملخص العربي}

تأثير اختلاف فصول السنة على أداء نمو بداري التسمين والحالة الفسيولوجية وحالة مضادات الاكسدة

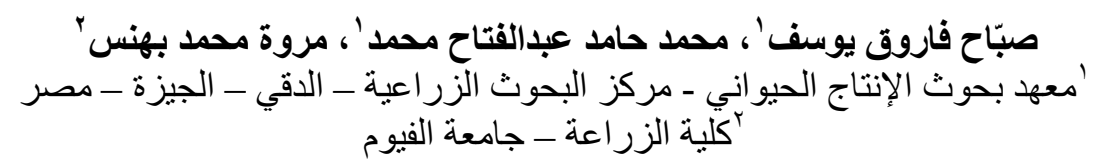

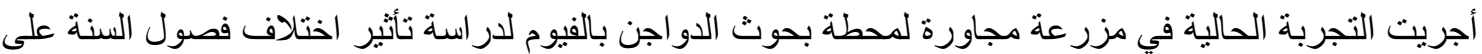

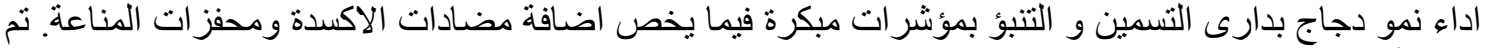

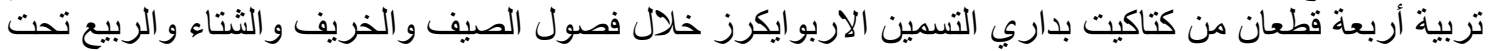

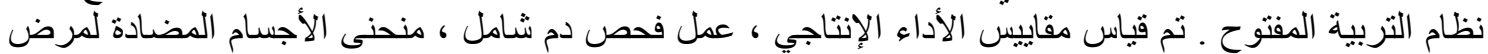
النيوكاسل (NDV) و أنفلونزا الطيور (H) تم الحصول على النتائج التالية: سجل وزن الجسم و الزيادة في وزن الجسم أعلى القيم معنوياً خلال فصل الربيع ولكن سجلت أعلى قيمة معنوية

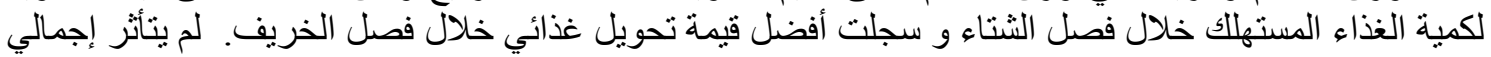

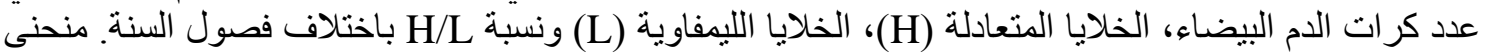
الأجسام المضادة لمرض النيوكاسل (NDV) و أنفلونزا الطيور (H)

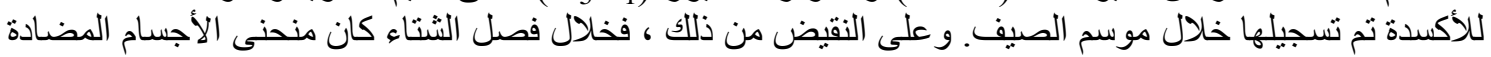

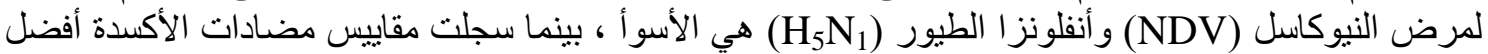
القيم لها.

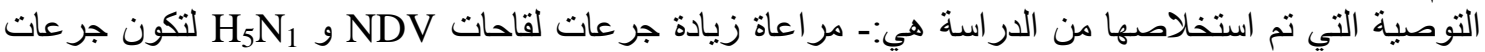
مضاعفة خلاّل الثتاء وزيادة مضادات الأكسدة في عليقة البداري أو حتى مياه الثرات لثرب خلانل كلا من فصلي الصيف و الخريف. الكلمات الدالة: بداري التسمين، فصول السنة، الأداء، مضادات الأكسدة، المناعة. 